\title{
P REFACE
}

Thomas R. Hester

THE LENGTHY BOR DER between the United States and Mexico has been the focus of scholarly research into the evolving nature of frontiers for many years. Studies of the traits of its economies, politics, health care, patterns of human immigration, architecture, history, and archaeology are but a few of the numerous kinds of investigations that deal with "the Borderlands." A major overview of this vast region, Borderlands Sourcebook: A Guide to the Literature on Northern Mexico and the American Southwest, was assembled and edited by Ellwyn R. Stoddard and others in the early 1980 os (University of Oklahoma Press, 1983).

Most of the border passes through arid to semiarid environments, and this dry, desolate countryside has attracted only the most dedicated fieldworkers from a variety of fields. From the standpoint of its ancient cultures, it has been assumed that not much of importance went on in prehistoric times in the Borderlands context, most especially along the Texas-Mexico frontier. Ethnologists have painted a stark picture of hunters and gatherers always on the edge of famine and with a limited material culture. The farming cultures of the Southwest were studied in isolation, with little consideration of their possible roots in northern Mexico. Archaeological work in the late twentieth and early twentyfirst centuries, much of which is reported in this volume, has helped to change this view. Similarly, modern ethnohistorical research of the type done by Maria Wade demonstrates the changing nature of Borderlands societies in light of the relationships, during the sixteenth to eighteenth centuries, among native peoples in the area between the southwestern Edwards Plateau and the deserts of northeastern Mexico. A great amount of insight is provided into the dynamic interactions (involving hunting, trade, and use of the landscape) among Indian groups as well as the mechanisms utilized by some of these groups to manipulate the early Spanish explorers. The view presented by Wade in The Native Americans of the Texas Edwards Plateau, 1582-1799 (University of Texas Press, 2003) is one that might well be projected back in time, especially in the review of prehistoric settlement patterns and tool assemblages. 
With this background, it is clear that the present book, ably pulled together and edited by Bradley J. Vierra, is a significant step in furthering our understanding of Borderlands prehistory. In northern Mexico and the American Southwest, the Borderlands provide a fertile "laboratory" for studying the transition from hunting and gathering to the introduction of agriculture. The Arizona-Sonora area is the subject of chapters by Carpenter, Sánchez, and Villalpando C. and by Mabry. Discoveries of early agriculture in Chihuahua are discussed by Hard and Roney, Doleman, and Ogilvie (the last based on biological research). The persistence of hunting and gathering is notable along the Texas-Mexico border; the chapters by Mallouf, Dering, Vierra, and myself showcase the variability in these groups, although our knowledge still has many shortcomings.

Vierra's book also emphasizes that a lot of additional research will be needed in the Borderlands to define the full range of ancient cultural variation. For example, a unique area not covered in the present book needs to be briefly noted. The lower Rio Grande and its delta constitute a subtropical zone not seen elsewhere along the border. Hunters and gatherers lived on both sides of the Rio Grande, and frontier Mesoamerican cultures were present farther down the Mexican Gulf coast. While we have long known of the special trade relations between the Mexican agriculturalists and the delta hunters and gatherers (involving the trade in ceramics, jade, and obsidian into the delta), we have only recently learned that this process began much earlier than previously thought. For years my own research, and that of other colleagues interested in the delta, has indicated that this pattern of interaction was restricted to Late Prehistoric times (the "Brownsville Complex"), featuring the Late Postclassic Huastecan culture as the source of these exotic artifacts. Recent reanalysis of some of the cemetery sites (where jadeite and nonceramic trade goods have been found), however, places the emergence of the interaction back into the Late Archaic, around 1500 BC. Now we have to wonder if the Olmec and related Preclassic cultures of the Mexican Gulf Coast were the first to establish trade relations with the peoples of the Rio Grande Delta. The reanalysis of the antiquity of trade in the delta is a measure of how fast our views of the Borderlands are changing — changes that will be enhanced by the research avenues outlined in this book. 